\title{
Assessing the drivers of the regional digital divide and their impact on eGovernment services: Evidence from a South American country
}

Mónica Pazmiño-Sarango (Universidad Técnica de Cotopaxi, Latacunga, Ecuador)

Mijail Naranjo-Zolotov (NOVA Information Management School (NOVA IMS), Universidade Nova de Lisboa, Lisbon, Portugal)

Frederico Cruz-Jesus (NOVA Information Management School (NOVA IMS), Universidade Nova de Lisboa, Lisbon, Portugal)

This is the accepted author manuscript of the following article published by EMERALD:

Pazmiño-Sarango, M., Naranjo-Zolotov, M., \& Cruz-Jesus, F. (2021). Assessing the drivers of the regional digital divide and their impact on eGovernment services: evidence from a South American country. Information Technology and People. [Advanced online publication in 21 September 2021]. https://doi.org/10.1108/ITP-09-2020-0628

This work is licensed under a Creative Commons Attribution-NonCommercial 4.0 International License. 



\section{Assessing the drivers of the regional digital divide and their impact on eGovernment services: Evidence from a South American country}

Design/methodology/approach:

The paper used an exploratory approach. We empirically assessed the provision of eGovernment services in each of the 36 Ecuadorian local governments following the LOSI measurement scale proposed by the United Nations, and then evaluated the drivers of the eGovernment divide at a local level. We used ordinary least squares regression analysis.

\section{Purpose:}

The paper explores the main drivers of the regional-level digital divide in Ecuadorian cities and the extent to which the Information and Communication Technology (ICT) adoption by citizens influences local-level policymakers' decisions to develop e-Government services.

\section{Findings:}

The findings indicate that the digital divide is driven by income and education disparities, and that e-Government availability is driven by ICT use. It appears that proper attention to technology use by its citizens is not being given by local-level policymakers in Ecuador when they devise their eGovernment strategy.

\section{Research limitations/implications:}

Because the data were available at different levels of aggregation, there may be some inaccuracy of the indicators and lack of generalizability. Researchers are encouraged to test our hypotheses with data at lower levels of aggregation and from different latitudes to provide a comparative view between countries.

\section{Practical implications:}

The paper includes implications for policymakers and local authorities regarding how the limitations on e-Government development may be mitigated.

Originality/value:

This study fulfils the need to assess digital development and its impact on e-Government services at a city level in a developing country.

Keywords: e-Government, municipalities, Latin-America, digital divide, LOSI scale 


\section{Introduction}

Information and communication technologies (ICT) play an important role in virtually every aspect of our existence. Even in the present times, when the COVID-19 pandemic imposes lockdowns and social distancing throughout the world, ICT have an even greater importance, as the distance imposed between people, firms, and public organizations is tackled through these technologies. ICT's importance for global development has been acknowledged by leading organizations, economic blocs, and countries (see, e.g., European Commission, 2010; United Nations Development Programme, 2016; World Bank, 2016). A prominent example of how ICT can positively affect one's life is through e-government at both national and local levels.

In the context of developing countries, local governments are especially important as they aim to increase transparency, accountability, and civic engagement by making public services delivery more effective, accessible, and responsive to citizens' needs, improving the relationship between citizens and their governments and promoting more inclusive societies (Feeney and Brown, 2017; United Nations, 2016).

Citizens and governments have more interaction at a local level. For instance, citizen involvement in consultation in the decision-making process is much more substantial with governments at a local level than at a national level (Naranjo-Zolotov, Oliveira and Casteleyn, 2019). However, in order for one - whether an individual, firm, or community - to achieve the benefits of e-government (eGov), access to Information and communication technologies is required, which often does not happen even in developed, but more so in developing countries. Asymmetries in ICT access (and use) are thus a primary concern for central and local governments and other stakeholders interested in promoting eGov and civic participation, as they prevent citizens from taking full advantage of the benefits of eGov. Disparities in e-government development exist across countries, regions, and cities, depending upon their specific characteristics (United Nations, 2014).

Nevertheless, e-government asymmetries are more notable in developing countries, where ICT asymmetries are also prevalent. Ironically, it is in these areas where e-government's benefits would be more noticeable. Thus, the assessment of the levels of eGov services development and how it is related with citizens' access to ICT, at a local level in developing countries, is paramount in order to design more-tailored public policies and strategies to bridge the differences between local governments and increase the levels of eGov adoption by citizens. 
Despite its importance and the growing interest in I.S. literature, most research on eGov has been focused on central-level services and at a country level (Valdés et al., 2011) especially in developed countries (Bonsón et al., 2012), precisely neglecting those who could benefit the most with eGov (Sandoval-Almazan and Gil-Garcia, 2012). This fact reveals a serious caveat - one country might be overall well in terms of eGov availability and use while nevertheless disguising meaningful disparities that go unnoticed, as data are analysed at a national level. Although this may in fact occur every time one looks at aggregate national data, in the e-government field the danger is even greater, as eGov is very often dependent upon local-level initiatives (Krishnan et al., 2013). This study addresses this issue by assessing digital development and eGov development at a local level in Ecuador, a developing country. Accordingly, this work aims to answer the following research questions:

1. What are the main drivers of the regional-level digital divide in Ecuadorian cities?

2. To what extent does ICT adoption by citizens influence local-level policymakers' decisions to develop e-government services?

By answering these research questions the article makes two contributions to research and practice. First, we assess the provision of eGov services in each of the 36 Ecuadorian municipalities following the LOSI measurement scale proposed by the United Nations (2016a). Second, we evaluate the drivers of the eGov divide at a local level in a developing country (United Nations, 2018a). From the ordinary least squares (OLS) regression analysis, we provide evidence that at local levels the public administration provides more advanced eGov services when the population has higher levels of ICT access, education, and income. Furthermore, we provide insights that may help local governments design more accessible eGov services.

The remainder of the paper is organized as follows: Section 2 presents the theoretical background, Section 3 the framework, and Section 4 the analysis. Sections 5 and 6 present the results and discussion, respectively. Section 7 ends with the research conclusions. 


\section{ICT widespread and e-government development}

\subsection{The digital revolution and the rise of a digital divide}

In recent decades ICT have completely revolutionized the way individuals and firms interact with each other. Less than 60 years ago the first fully electronic calculators were developed and released into the market with an initial cost above 1,000 USD. At the time, these were more expensive than some houses; whereas today, for a fraction of that price, one can buy a simple electronic device that can store more documents than the average number of books and serial volumes existing in U.S. public libraries - 85,250 according to the National Center for Education Statistics of the U.S Department of Education. Likewise, as recently as the 1950s, long-distance communications were undertaken mainly via postal services or telephone, whereas presently much of the world is connected via digital networks that allow incredible volumes of data to be exchanged instantly. The ICT (digital) revolution has been astounding, and there is evidence that the pervasiveness of ICT will continue to grow at an increasingly faster pace. The impact of ICT ranges from science, services, agriculture, and manufacturing. ICT development goes hand in hand with innovation, creating a snowball effect from which individuals, firms, communities, and countries can benefit.

As Gurstein (2003) explains, "ICT provides the basic infrastructure for production, and dissemination in any area of activity which has a significant information, knowledge or learning component". Carlsson (2004) examined the effects of ICT in the economy, comparing these to the so-called "general-purpose technologies (GPT) which in the past revolutionized the economy", such as the transportation technologies in the 19th century, the steam engine, or the electric motor, finding that ICT appear to exert an even higher influence on the economy as "it affects the service industries (e.g., health care, government, and financial services) even more profoundly than the goodsproducing industries, and these service sectors represent over 75\% of GDP".

Concordantly, Jalava \& Pohjola (2008), analysed ICT's contribution to Finland's GDP between 1990 and 2004, pointing out that the impact of these technologies was three times greater than the contribution of electricity from 1920 to 1938 . ICT is as important, if not even more so, in developing countries than it is in developed ones, as these technologies provide the fastest and most efficient way for development. In developing contexts, ICTs (e.g., mobile phones, Internet broadband) positively influence virtually every aspect of development and well-being (Victory and Cooper, 2002); e.g., farmers in gaining access to market prices, micro- and small-businesses to proliferate, facilitating education and health access, creating ICT-based jobs, and incentivizing political 
participation, among many others (for a detailed explanation of ICT for development, see Heeks, 2018).

ICT is very likely the key general-purpose technology (technological innovations that have the potential to improve most industries and society sectors) of the present day (Bresnahan and Trajtenberg, 1995; Doong and Ho, 2012; European Commission, 2013). ICT is now pervasive as it influences virtually every aspect of our daily lives (The World Bank, 2009). At an individual-level, ICT enables new types of interactions and advanced services provided by organizations. These include e- and m-commerce, e-government, e-health, e-learning, e-banking, m-banking, social networks, cloud computing, and many others (Van Bardeleben, 2011; Çilan et al., 2009; Krishnan and Lymm, 2016; Vicente and Gil-de-Bernabé, 2010; Vicente and López, 2010a; Zhao et al., 2012). Moreover, ICT positively affects the economy and welfare in several important dimensions (Çilan et al., 2009; World Bank, 2006). It creates competitive advantages in enterprises, improves national health systems (Bakker, 2002), optimizes educational systems (Hsieh, Rai and Keil, 2008; Ćukušić et al., 2010), boosts civic participation (Naranjo-Zolotov, Oliveira, Cruz-Jesus, et al., 2019), which in turn creates new opportunities. All of these reduce distance constraints and create new industries that generate new employment opportunities (Castells and Himanen, 2011; Ignatow, 2011).

\subsection{Digital divide}

As ICT become pervasive, so did inequalities in its access- often called the "digital divide". Although it is not clear who first employed the term (Gunkel, 2003), it can be traced back to the mid-1990s and is usually attributed to the former Assistant Secretary for Communications and Information of the United States (US) Department of Commerce, Larry Irving Junior (Dragulanescu, 2002). He used the term to simply describe the social division between those who were involved with ICT and those who were not. The digital divide was initially understood as a binary view, meaning that there was a choice between "have" and "have not" access to ICT (van Deursen \& van Dijk, 2015). As ICT capabilities and pervasiveness expanded, so did the understanding regarding unequal access and use. Perhaps one of the most important contributions to raising awareness about this subject was the popular "Falling through the Net" Reports. In this series of reports the definition of digital divide evolved from simple PC ownership to the inclusion of Internet access, to the availability of broadband connections, and to the other and more advanced types of ICT use. As the digital divide's antecedents, it was discovered that living areas were an important factor in drawing a line between information haves and have-nots. Individuals belonging to ethnic minorities, or with lower incomes, 
were also more vulnerable to asymmetries in the access to digital technologies (Cruz-Jesus et al., 2012; Elena-Bucea et al., 2020). In other words, the understanding of ICT asymmetries evolved considerably as the subject came to be understood as a multidimensional and complex issue. A still widely accepted definition for the digital divide is the one provided by the Organization for Economic Co-operation and Development (OECD): "the term digital divide refers to the gap between individuals, households, businesses and geographic areas at different socio-economic levels with regard both to their opportunities to access ICT and to their use of the Internet for a wide variety of activities" (OECD, 2001).

\section{First- and second-order digital divide}

Asymmetries in ICT access and use are known, respectively, as first- and second-order (Dewan and Riggins, 2005). The first-order relates to having, or not, (physical) access to ICT, whereas in the second-order the problem resides in different use patterns among those who already have (very similar) access to ICT (e.g., using the Internet "just" for browsing or email vs. using it for learning, or seeking employment or health information). As noted by Epstein, Nisbet, \& Gillespie (2011), different types of asymmetries (first- or second-order) require different actions from different entities. To bridge the first-order divide, for example, ICT subsidization, provided by public authorities, is often tried; whereas to bridge the second-order divide, ICT training, which can be provided by private stakeholders and institutions, may work better. Hsieh, Rai, \& Keil (2008) found that in the United States, even when people from different socioeconomic backgrounds have similar access to ICT (i.e., the first-order divide is bridged), it is likely that they exhibit different patterns of post-implementation ICT use, thus showing evidence of a second-order divide. They concluded that economically advantaged people have a "higher tendency to respond to network exposure", using ICT with much more confidence than the disadvantaged.

Other studies also found evidence that domestic divides may be hidden in countries recognized as digital leaders (e.g., Cruz-Jesus, Vicente, Bacao, \& Oliveira, 2016). In the Netherlands, for example, van Deursen \& van Dijk (2015) found that those who are younger, more educated, and with higher incomes are more likely to have better Internet access. Nowadays, in the IS literature, it is fairly well accepted that ICT access asymmetries are largely bridged in developed countries but in developing countries that is not the case. Nevertheless, even in developed countries, second-order divides are still an important issue, especially for disadvantaged people such as the elderly, those with lower 
socioeconomic status, those who are impaired, or ethnic minorities (e.g., Blank, 2013; Lindblom \& Räsänen, 2017).

\section{Third-order digital divide}

In recent years researchers have turned their attention to a different type of ICT asymmetry - that related to outcomes. ICT is not an end in itself, but rather a means to achieve a better quality of life and well-being. Wei, Teo, Chan, \& Tan (2011) were perhaps the first to call attention to what is now known as the third-order digital divide. In their work, based on social cognitive computer selfefficacy literature, they demonstrated that depending upon different aspects, ICT use may yield different outcomes. Among these are higher income or other monetary aspects, better education, health, culture, social relationships, among others (e.g., van Deursen \& Helsper, 2015 for a comprehensive description).

Van Deursen \& Helsper (2018) studied the determinants of five types of ICT outcomes (economic, social, political, institutional, and educational), corresponding to the five types of the Internet uses proposed by van Dijk (2005). Their work revealed that different types of outcomes have different antecedents, which is, to some extent, surprising. Although limited to the Netherlands - one of the most digitally developed and homogeneous countries in this regard (e.g., Cruz-Jesus et al., 2012; Cruz-Jesus, Vicente, Bacao, \& Oliveira, 2016b) - gender is still important in social and political ICT outcomes. Note that in developed countries the gender-related digital divide is usually assumed to be bridged (Elena-Bucea et al., 2020). Age, which is recognized as one of the most important drivers of digital inequalities, was shown to be especially important for economic/employment outcomes but not, for example, in health-related ones.

Van Deursen \& Helsper (2018) add further detail to this line of research in their work, in which they studied which types of ICT use led to different outcomes (other than the specific type of use). They divided ICT use and outcomes into economic, cultural, social, and personal. Using a representative sample of 1,101 Dutch individuals, they concluded that the type of ICT use was more relevant than one's demographic characteristics. Scheerder, van Deursen, \& van Dijk (2017) conducted a comprehensive literature review on digital divide, finding that fewer than $7 \%$ of the articles addressed third-order (outcomes) inequalities, as the vast majority of studies focused on secondorder ones (81\%). The third-level digital divide in poor and underprivileged contexts, such as developing countries, is an even more promising and, ironically scarce, research stream. This gap 
had already been identified by Venkatesh and Sykes (2013) when they called for studies that, although include ICT outcomes as "economic, health, and quality of life benefits, there is limited systematic empirical evidence documenting that such benefits are indeed derived".

\section{ICT for development (ICT4D)}

The opportunities that ICT outcomes present to those living in developing countries are tremendous (Venkatesh et al., 2016), and have received attention from governments and NGOs in developing regions around the globe. The role that ICT may have for development is constantly pointed out by researchers and policy-makers, including in the context of the UN's Sustainable Development Goals (SDG) (United Nations, 2015a, 2018b). Moreover, a recent study conducted by Lee, Shao, \& Vinzé (2018) found evidence that developing economies are precisely those that benefit the most from ICT investments.

Venkatesh, Sykes, \& Zhang (2020) showed that Internet kiosks may yield positive health outcomes in rural India, namely regarding health information and deduced maternal mortality. They developed a conceptual model for ICT health outcomes based on adoption at two different levels: individual- (women), and village-level (lead user - the person/entity that first used the Internet kiosk). Grounded in social network theory, four constructs were hypothesized to explain ICT (i.e., Internet kiosks) use that influenced the search for health-related information and, consequently, a drop in maternal mortality rates. Time was also included as a moderator of some of these relationships. The model was tested on more than 6,000 women over a period of seven years, and the results showed the importance of network effects in ICT4D initiative success. The authors' hypotheses were largely supported, as the network variables at different levels played an important role in explaining the use of Internet kiosks (43\% of variance explained), in seeking modern medical care $(46 \%)$, and in reducing maternal mortality $(48 \%)$.

In addition to the individuals' and environmental characteristics, other features related to the ICT4D project itself can play a role in determining its success. An example of these (other) aspects is given by Venkatesh, Sykes, Rai, \& Setia (2019). These authors extended the model that had been previously proposed by Venkatesh \& Sykes (2013), which was grounded in network connections, such as behavioural and informational pathways, by adding the governance model to understand ICT4D success. Venkatesh, Sykes, Rai, \& Setia (2019) considered four types of governance models in ICT4D initiatives, combining two different types of leadership (by the local government or a 
technology sponsor) in two different stages (the pre- and post-launch). They hypothesized and eventually confirmed that those hybrid models would perform better, especially those in which local governments led the pre-launch and the technology sponsor the post-launch. Their findings are critical to the ICT4D literature, as they further expand the success factors to include governance.

The vast number of potential drivers (and inhibitors) of ICT use is probably the main reason why the role of ICT4D is still largely untapped and many initiatives in this context eventually fail (Venkatesh et al., 2020). In this sense, one may wonder if the typical ICT4D approach, i.e., to subsidize or make available public (free) ICT access points, is the most efficient one. As we know from surveying the literature, even when access to ICT is granted, other factors may prevent its actual use and, consequentially, its outcomes. In this context, it should be kept in mind that, as Ojo (2016) argues, ICT4D is not only about providing access technology, but rather about how people (effectively) use it to improve their well-being. Hence, the whole ICT adoption-to-outcome process, especially in developing contexts, is a complex one. This fact is well known by researchers and practitioners and is noticeable in studies examining ICT4D.

Coincidentally, it seems plausible to assume that ICT post-adoption (that is, from access and use to outcomes) is even more complex than is the process leading up to the first use. As GPT, ICT can be used for a virtually unlimited number of activities (purposes). Virtually every ICT4D study is focused on one of these (e.g., health, income, education), but not on multiple outcomes at the same time. Furthermore, there is a clear gap in studies examining how ICT may yield, simultaneously, positive and negative outcomes of different types. Is it not reasonable to assume that even in developing contexts, ICT may create greater revenue streams, as shown by Venkatesh \& Sykes (2013), but, at the same time, also affect those same streams by, for example, leading to the procrastination of important work-related activities? Is it not possible that by using ICT, one might benefit in economic terms but lose in health terms, at the same time? It is hard to imagine that this cannot happen, as it does in developed contexts with social media, for example. These are questions that are worth investigating that so far have not been.

There are two types of digital divide; one located at an international level, that is, between different countries, whereas the other is at an intra-national level or within a country. In both types, gaps can occur regarding access to ICT between regions or groups of individuals when characteristics of different nature exist (Ono and Zavodny, 2007; UNESCO, 2009). Some authors have demonstrated 
that the domestic digital divide is characterized by a higher risk of digital exclusion of the elderly, women, those with lower income, and education attainment, those with disabilities, those living in rural areas, and ethnic minorities (Adams, 2000; Cruz-Jesus, Vicente, et al., 2016; Elena-Bucea et al., 2020; Vicente and López, 2010b). Moreover, according to Riggins and Dewan (2005), digital disparities may also be found at an organizational level, in which "large organizations are more likely to adopt innovations and advanced ICT solutions than smaller organizations".

Policymakers at all levels exercise the most significant power and effectiveness in narrowing the global digital divide. For this reason, this work is mainly focused on the regional-level (domestic) digital divide and its main drivers. A conceptualization of the digital divide phenomenon, provided by Elena-Bucea et al. (2020), is presented in Figure 1.

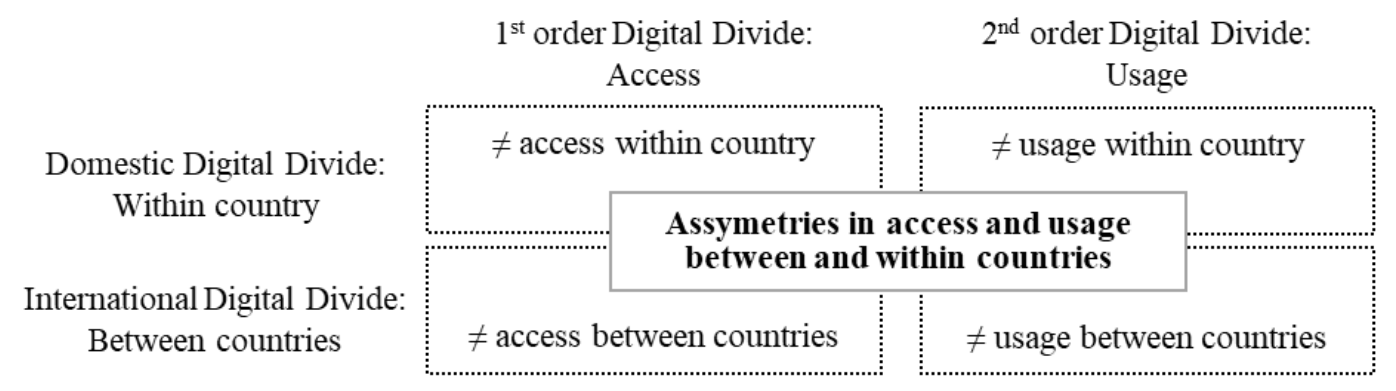

Figure 1. Conceptualization of digital divide provided by Elena-Bucea et al. (2020).

\section{3. e-Government}

The United Nations defined eGov as "the use and application of information technologies in public administration to streamline and integrate workflows and processes, to effectively manage data and information, enhance public service delivery, as well as expand communication channels for engagement and empowerment of people". eGov appeared in the mid-1990s (Zhao, Collier, et al., 2014) and rapidly evolved, most of the time in line with ICT advances, from simply providing information through official public administration web portals up to the use of disruptive technologies such as artificial intelligence (AI) and Internet of things (IOT) to provide electronic services that contribute to the improvement of the quality of citizens' lives (Eggers, Schatsky and Viechnicki, 2017; Mehr, 2017).

The eGov services that citizens use more often and the ones that have a more substantial impact in their daily life are the ones provided by the local governments, more specifically, at a city or municipality level (Cegarra-Navarro et al., 2012). EGov services to citizens can range from the 
electronic payment (e-payment) of taxes or utilities (Hung, Chang and Yu, 2006), to services for online citizen participation and deliberation in decision-making processes (Kersting, Gasparikova and Iglesias, 2016), or provision of open data (Weerakkody, Irani, Kapoor and Sivarajah, 2017). In the local eGov context, active online citizen participation in the decision-making process is one of the key factors for successful public administration (UNPAN, 2012).

Despite the potential benefits of eGov services for citizens, not all local governments have achieved desirable levels of eGov development for their municipalities. Previous literature in the context of eGov adoption at the individual level suggests that factors such as socio-economic background, education, age, ICT access, and skills play a critical role in the eGov divide amongst individuals (Bélanger and Carter, 2009; Chris Zhao and Zhu, 2014). Indeed, there are significant disparities in eGov development levels amongst countries (United Nations, 2018a). The adoption of eGov at an individual level may also affect the strategic decisions of local governments regarding whether to invest in technologies and processes and eGov services targeting their citizens. These include mobile government (m-government) (Almuraqab, 2017); technologies to empower citizen engagement (Bataineh and Abu-Shanab, 2016); co-creation (Khan and Krishnan, 2021); and boosting civic engagement (Hassan and Hamari, 2020; Stratu-Strelet et al., 2021). Therefore, we hypothesise that besides ICT access, socio-economic factors such as age, education, income, and population density (rurality) also impact the level of eGov services' availability between cities in a developing country.

\section{Context and research model}

\subsection{Ecuadorian context}

Ecuador is an interesting context in which to study the eGov divide at the municipality level. This South American country has important characteristics that may bring valuable insights for other developing countries: (i) Ecuador improved its e-government development index (EGDI) from the $95^{\text {th }}$ position in 2010 to the $84^{\text {th }}$ position in 2018 (the number of countries ranked also increased in these years from 184 to 193). In the South-American region, Ecuador was the second-best in improving EGDI positions, after Brazil (United Nations, 2010, 2018a), as seen in Table I; (ii) The municipalities with more than 80,000 inhabitants in Ecuador account for approximately two-thirds of its entire population. Most of the insights about eGov services development found in the literature are based on the results of studies from eGov services in big cities or at a national level (Jeff Gulati, Williams and Yates, 2014; Ma and Zheng, 2019), which may not reflect the reality in the 
rest of the country. (iii) besides its EDGI, Ecuador is also ranked in the middle of the world list of countries from top to bottom of the gross domestic product (GDP) per capita (United Nations, 2018c); and, (iv) Ecuador is considered a very multi-culture and multi-ethnic country (Bowen, 2011; Novo, 2014; Radcliffe, 1999), which means that even at a municipality level the need for eGov services may be quite diverse and the involvement of citizens in e-participation processes could be a challenge. In summary, Ecuador is a country that has an average world position in its digital, economic, and eGov development indicators. As most countries are categorized as developing countries, the results from this study may provide useful insights for local governments that wish to improve their levels of eGov services development. The development of eGov services dramatically contributes to achieving several sustainable development goals, for instance, "11-sustainable cities and communities", and "16-peace, justice and strong institutions" proposed by the United Nations for 2030 (United Nations, 2015b).

Table I. World e-government development ranking progress (2010/2018)

\begin{tabular}{llll}
\hline Country & $\mathbf{2 0 1 0}$ & $\mathbf{2 0 1 8}$ & $\begin{array}{l}\text { Evolution } \\
\mathbf{2 0 1 0 - 2 0 1 8}\end{array}$ \\
\hline Brazil & 61 & 44 & 17 \\
Ecuador & $\mathbf{9 5}$ & $\mathbf{8 4}$ & $\mathbf{1 1}$ \\
Suriname & 127 & 116 & 11 \\
Argentina & 48 & 43 & 5 \\
Uruguay & 36 & 34 & 2 \\
Bolivia & 98 & 103 & -5 \\
Paraguay & 101 & 108 & -7 \\
Chile & 34 & 42 & -8 \\
Peru & 63 & 77 & -14 \\
Guyana & 106 & 124 & -18 \\
Colombia & 31 & 61 & -30 \\
Venezuela & 70 & 106 & -36 \\
\hline
\end{tabular}

Ecuador has a population of approximately 17 million. The country is organized in 24 provinces, and each province is subdivided into municipalities (also called cantons) that include urban and rural areas within their borders. There are 224 municipalities, and each has one local government that includes a mayor and several council members. These local governments are in charge of providing services and creating policies for both urban and rural areas. The web portals of the 36 local governments of middle size and big municipalities are assessed in this study. We collected data on municipalities of 80,000 inhabitants or more. 
The local governments in Ecuador oversee the provision of several services to the citizens including water management, waste management, sewage management, transit management, records management, creation of land use policies, and others. Consequently, the implementation of eGov services can help citizens to save considerable time and money when doing tasks such as online payments (utilities, taxes, etc.) and online incident reporting. Local governments interact closely with citizens, which creates the need to implement online citizen participation tools (eparticipation) (Naranjo-Zolotov, Oliveira and Casteleyn, 2019) that may help to make consultation and decision-making processes more inclusive.

In the Ecuadorian context, even though it is a relatively small country, the lifestyle, culture, production, industries, and geographies can change dramatically from one city to another. For instance, the lifestyle in a city located at sea level can be very different from the lifestyle of a city located at 2500 meters above sea level. Thus, we may expect to have vast imbalances in ICT access and e-government services amongst cities.

\subsection{Research model}

As mentioned earlier, this study's objectives are twofold: (i) understand the determinants of the Ecuadorian regional-level digital divide; and (ii) assess the extent to which the e-government availability is dependent upon the local-level digital divide, i.e., ICT adoption. These two objectives are depicted in Figure 2.

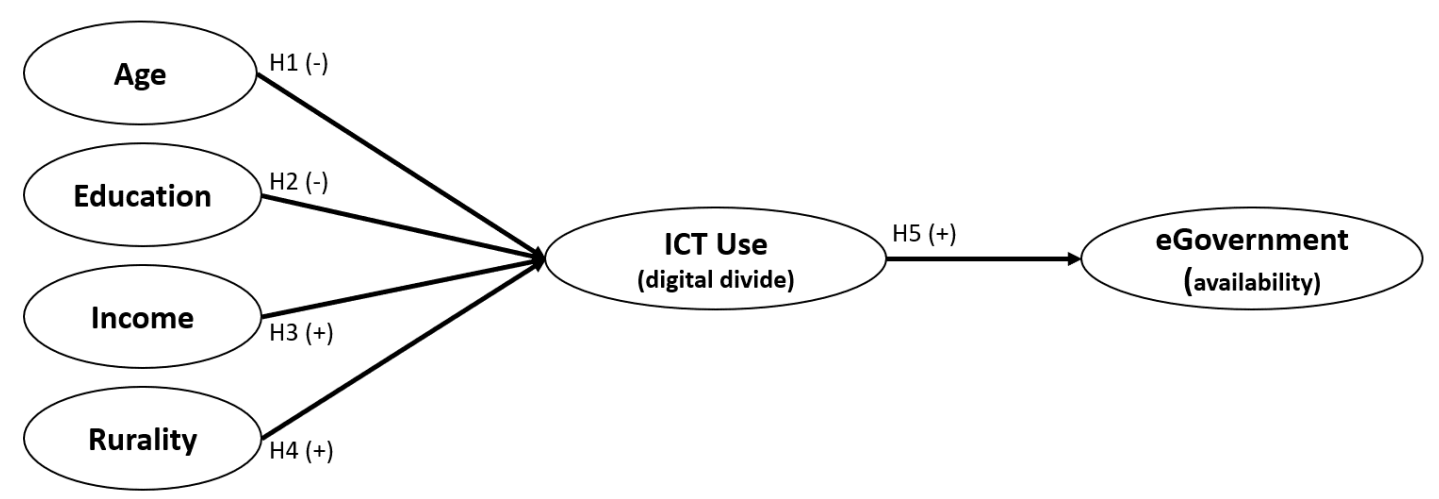

Figure 2. Research model

To answer the first research question, we used data following the recommendations of the United Nations to measure the ICT development (United Nations, 2018a), and the variables available at the 
INEC (INEC, 2017), which is the institution officially responsible for collecting and publishing Ecuadorian statistics. As we need to have a measure of eGovernment availability in the 36 municipalities in the study to answer the second research question, we scored the existing eGov web portals in each city using the Local Online Service Index (LOSI) (United Nations, 2018a). The LOSI was preferred over other models of e-government assessment (Andersen et al., 2011; Das et al., 2017; Sangki, 2018; Valdés et al., 2011) because the LOSI includes very specific items tailored to local governments, for instance: reporting of occurrences in public spaces or participatory budgeting. The LOSI scale items are organized in four categories: (i) Technology, (ii) Content provision, (iii) Service provision, and (iv) Participation and engagement. From the original list of the 60 LOSI scale items (United Nations, 2018a), 7 were dropped, either because the items could not be assessed or because the items will not reveal any difference among local governments.

The assessment began in the central-local government's website and then explored the links to the online services provided. If the web portal complied with the condition, it scored one (1); otherwise, it scored zero (0). The evaluation of the websites was performed in the first trimester of 2021 . The LOSI score is expressed as a percentage of the 53 items assessed. Note that the LOSI score is represented as the eGovernment availability in the research model (see Figure 2).

\subsection{Hypotheses}

Despite the tremendous potential that ICT has to foster economic growth and welfare, the fact is that these technologies may actually, to some extent, drive inequalities instead of fixing them (Park et al., 2015). This phenomenon is likely to happen when there are substantial asymmetries in access to these technologies by subsegments of individuals. As pointed out by Van Deursen, Van Dijk, and Ten Klooster (2015) and Yu (2011), one's socio-demographic aspects affect online behaviours. In the digital divide literature, depending upon the context and level of analysis, there are clearly six main factors that are known for being potential drivers of the digital divide: age, education, ethnicity, gender, income, and geographical area (Dewan and Riggins, 2005; Elena-Bucea et al., 2020). In a nutshell, the elderly, those with lower education, those belonging to ethnic minorities, females, those with lower income, and those living in rural areas are more likely to be on the wrong side of the digital divide, i.e., having lower access to ICT. In the context of our study, i.e., assessing the regional-level digital divide in a developing country, we analyse four of the potential drivers: age, education, income, and rurality. This decision was taken because ethnicity and gender are particularly crucial at an individual level, although not as much at a municipality level. Differences 
across regions are small, potentially meaningless, and are for the most part accounted for by the others, which present more information. In particular, for ethnicity, municipalities with a higher percentage of ethnic minorities are very likely also those with lower levels of income and education. As for gender, there is substantial evidence that it may drive digital inequalities in some particular cultures, usually not in Western ones (Elena-Bucea et al., 2020). The next paragraphs develop the rationale for each of the four drivers tested in this context.

Age is a demographic variable that has been used in the literature as an indicator of individual differences regarding the digital divide and the adoption of technology (Venkatesh, Thong and Xu, 2012). This is so because, generally speaking, older persons are less prone to use ICT in comparison to youth. Thus, in order to fully understand the digital divide, considering age-related differences is a matter of critical importance (Barnard et al., 2013; Friemel, 2016; Mitzner et al., 2010). At the base of the age-related digital divide are the differences between those who were born and grew up with ICT and those who were not. Additionally, aside from the fact of growing up or not in the digital world, there is another factor influencing the relationship between age and ICT adoption: the consequences arising from the natural aging process. However, these tend to affect primarily the most elderly. The normal aging process almost inevitably tends to lead to physical and cognitive disabilities, which may cause digital exclusion (Czaja and Lee, 2007; Fozard, 1990). From what is stated above, we hypothesise that:

H1: Age is negatively associated with ICT usage.

Several education-related factors, for instance, the adult literacy rate, average years of schooling, or gross enrolment ratio, among others, have been extensively used in the literature to explain the digital development of countries (Billon, Marco and Lera-Lopez, 2009; Shirazi, Ngwenyama and Morawczynski, 2010). eGov development can also be explained by education (Zhao, Collier and Deng, 2014; UN, 2016). The rationale behind this is that more-highly educated individuals are more likely to adopt ICT tools for their daily and work activities, and that includes eGov services. In developing countries people with higher levels of education are more likely to have access to ICT tools, as for instance a personal computer. Nevertheless, in the last decade, the emergence and availability of mobile technologies at lower prices has helped to reduce the gap regarding the ICT adoption between different levels of education (Ochara and Mawela, 2015). eGov services at a local level are usually designed to be easily used and adopted, even for those with low levels of education. 
To test our hypothesis, we selected the literacy rate per municipality, which may show significant disparities from one municipality to another in developing countries.

H2: Education is positively associated with ICT usage.

The association between economic factors and ICT adoption has been widely evaluated in the literature, confirming that wealthier countries and individuals are more likely to be the first to adopt ICT innovations (Cruz-Jesus, Oliveira, et al., 2016; Hietala, 1983). In the eGov field, the existing economic disparities between countries are also associated with the level of eGov development (United Nations, 2018a), i.e., developed countries perform better than developing countries regarding eGov service development.

The most popular and preferred economic factor used in studies to assess the digital divide and eGov development is the gross domestic product (GDP) (Zhao, Collier and Deng, 2014; Park, Choi and Hong, 2015; Cruz-Jesus, Oliveira and Bacao, 2018). GPD may be considered as a clear and accurate indicator of the economic strength of a country, and therefore as an excellent indicator for comparison studies at a country level. However, GDP data are not available at the municipality or city level. Therefore, we used the taxes collected in each municipality as an indicator of its wealth. The citizens of wealthier municipalities may show higher rates of ICT adoption, and therefore local governments could see more advantages in the implementation of eGov services. We hypothesize that:

H3: Income is positively associated with ICT usage.

It seems reasonable to expect that the degree of rurality of a region, proxied by population density, is an important driver of ICT usage. Rogers (2003) suggests that high-density areas are more likely to adopt technological innovations than less densely populated areas because areas with a higher population density are easier to connect, and the innovation is more observable. On the contrary, Forman (2005) found that larger areas are more likely to adopt ICT. In more recent years, internet connections have reached more and more distant areas, even in developing countries, thereby reducing the digital divide regarding access to ICT. Cruz-Jesus et al. (2018) found that the size of geographical areas is no longer a significant predictor of digital development. In developing countries the coverage of the internet service may still not be available in all rural and distant areas. Therefore, it is expected that in geographically extensive areas the provision of eGov services is less developed than in areas of smaller size. In this vein, we hypothesize:

H4: Rurality is negatively associated with ICT usage. 
Literature suggests that ICT infrastructure, especially internet access, has been positively associated with the development of eGov (International Telecommunication Union, 2018). Zhao et al. (2014) argued that internet access and internet skills are pre-conditions for internet use, and subsequently, internet use has a positive effect on eGov development. In developing countries, the levels of internet access have increased significantly in recent years (International Telecommunication Union (ITU), 2018b), consequently paving the way for greater development of eGov services and adoption by citizens. Moreover, the use of the Internet can be considered a channel for digital democracy (AlHujran, Al-Debei and Al-Lozi, 2014) that facilitates the interaction between governments and citizens, boosting citizen participation in eGov services and decision-making processes along with public authorities. Therefore, we hypothesize:

H5: ICT usage is positively associated with eGov availability.

\subsection{Data}

In order to identify the 36 municipalities with more than 80,000 inhabitants, we collected the data about the population size from the projections to the year 2019 published by the INEC (INEC, 2017) based on previous census data (the last Ecuadorian general census was in 2010). These municipalities account for approximately two-thirds of the country's total population. The other one-third is distributed among smaller cities and towns with fewer than 80,000 inhabitants (INEC, 2017). The indicators selected for this study are described in Table II.

Table II. Acronyms, description, and support for the variables

\begin{tabular}{|c|c|c|c|}
\hline Acronym & Measure description & Data Source & Support \\
\hline ICT Use & $\begin{array}{l}\text { Percentage of individuals using the } \\
\text { Internet in the last } 12 \text { months }\end{array}$ & (INEC) & $\begin{array}{l}\text { (Cruz-Jesus, Oliveira, et al., } \\
\text { 2016; United Nations, 2018a) }\end{array}$ \\
\hline Income & $\begin{array}{l}\text { Taxes collected (averaged per } \\
\text { capita). }\end{array}$ & (SRI) & $\begin{array}{l}\text { (Azam, 2015; Dias and Costa, } \\
\text { 2013; Zhao, Collier, et al., } \\
\text { 2014) }\end{array}$ \\
\hline Age & $\begin{array}{l}\text { Percentage of the population } 60- \\
\text { years and older per city. }\end{array}$ & (INEC) & $\begin{array}{l}\text { (Zhao, Collier, et al., 2014; } \\
\text { Zolotov et al., 2018) }\end{array}$ \\
\hline Education & $\begin{array}{l}\text { Percentage of citizens } 15 \text { years and } \\
\text { older who can both read and write. }\end{array}$ & (INEC) & $\begin{array}{l}\text { (Das et al., 2017; United } \\
\text { Nations, 2018a) }\end{array}$ \\
\hline Rurality & $\begin{array}{l}\text { Population density (number of } \\
\text { inhabitants per square kilometre) }\end{array}$ & (INEC) & $\begin{array}{l}\text { (Cruz-Jesus et al., 2018; } \\
\text { Forman, 2005) }\end{array}$ \\
\hline eGov & Local online service index (LOSI) & Calculated by authors & (United Nations, 2018a) \\
\hline
\end{tabular}

Today public administration offers diverse e-government manifestations and services. Local governments can use social networks to interact with citizens (Mossberger, Wu and Crawford, 
2013), web portals and online services (Sandoval-Almazan and Gil-Garcia, 2012), open data Government (Weerakkody et al., 2017), e-participation tools such as online participatory budgeting (Zolotov, Oliveira and Casteleyn, 2018), online tax payments (Asmi, Zhou and Lu, 2016), or even smart cities initiatives (Acedo et al., 2018; Pereira et al., 2017). We evaluate eGov services using the Local Online Service Index (LOSI) (United Nations, 2018a) for each local government web platform, both globally and for each of its four components (technology, content provision, service provision, and online participation). See Table III for the results of the LOSI assessment.

Table III. Results of the LOSI assessment for the 36 cities

\begin{tabular}{|c|c|c|c|c|c|c|}
\hline \multirow{2}{*}{ Municipality } & \multirow{2}{*}{ Population } & \multirow{2}{*}{$\begin{array}{c}\text { LOSI score (\% of } \\
53 \text { evaluated } \\
\text { items) }\end{array}$} & \multicolumn{4}{|c|}{ LOSI components } \\
\hline & & & $\begin{array}{l}\text { Technology } \\
\text { (\% of } 12 \text { ) }\end{array}$ & $\begin{array}{l}\text { Content } \\
(\% \text { of } 24)\end{array}$ & $\begin{array}{l}\text { Service } \\
\text { (\% of } 9 \text { ) }\end{array}$ & $\begin{array}{c}\text { E-participation } \\
(\% \text { of } 8)\end{array}$ \\
\hline Ambato & 382,941 & 88.68 & 66.67 & 95.83 & 100.00 & 87.50 \\
\hline Azogues & 85,030 & 60.38 & 66.67 & 58.33 & 44.44 & 75.00 \\
\hline Babahoyo & 173,917 & 60.38 & 50.00 & 66.67 & 44.44 & 75.00 \\
\hline Cayambe & 105,781 & 73.58 & 66.67 & 75.00 & 88.89 & 62.50 \\
\hline Chone & 131,358 & 75.47 & 58.33 & 75.00 & 100.00 & 75.00 \\
\hline Cuenca & 625,775 & 94.34 & 100.00 & 91.67 & 100.00 & 87.50 \\
\hline Daule & 168,144 & 73.58 & 66.67 & 79.17 & 66.67 & 75.00 \\
\hline Duran & 308,059 & 67.92 & 66.67 & 70.83 & 44.44 & 87.50 \\
\hline El Carmen & 109,466 & 58.49 & 66.67 & 58.33 & 44.44 & 62.50 \\
\hline Esmeraldas & 216,901 & 71.70 & 66.67 & 66.67 & 77.78 & 87.50 \\
\hline Guaranda & 107,590 & 64.15 & 75.00 & 70.83 & 33.33 & 62.50 \\
\hline Guayaquil & 2698,077 & 86.79 & 83.33 & 91.67 & 100.00 & 62.50 \\
\hline Ibarra & 217,856 & 79.25 & 66.67 & 83.33 & 100.00 & 62.50 \\
\hline La Libertad & 115,952 & 46.23 & 33.33 & 52.08 & 33.33 & 62.50 \\
\hline Lago Agrio & 117,048 & 73.58 & 91.67 & 66.67 & 66.67 & 75.00 \\
\hline Latacunga & 202,878 & 73.58 & 83.33 & 75.00 & 55.56 & 75.00 \\
\hline Loja & 269,017 & 79.25 & 75.00 & 79.17 & 77.78 & 87.50 \\
\hline Machala & 286,120 & 58.49 & 50.00 & 66.67 & 33.33 & 75.00 \\
\hline Manta & 261,713 & 81.13 & 58.33 & 83.33 & 100.00 & 87.50 \\
\hline Mejia & 105,637 & 64.15 & 50.00 & 66.67 & 66.67 & 75.00 \\
\hline Milagro & 197,245 & 67.92 & 66.67 & 70.83 & 55.56 & 75.00 \\
\hline Montecristi & 103,735 & 50.94 & 41.67 & 58.33 & 33.33 & 62.50 \\
\hline Orellana & 91,933 & 62.26 & 50.00 & 66.67 & 55.56 & 75.00 \\
\hline Otavalo & 124,140 & 71.70 & 66.67 & 66.67 & 77.78 & 87.50 \\
\hline Pasaje & 86,583 & 58.49 & 41.67 & 62.50 & 44.44 & 87.50 \\
\hline Portoviejo & 319,185 & 81.13 & 75.00 & 87.50 & 77.78 & 75.00 \\
\hline Quevedo & 210,461 & 64.15 & 75.00 & 62.50 & 33.33 & 87.50 \\
\hline Quinindé & 144,198 & 56.60 & 58.33 & 54.17 & 55.56 & 62.50 \\
\hline Quito & 2735,987 & 94.34 & 83.33 & 95.83 & 100.00 & 100.00 \\
\hline Riobamba & 261,360 & 79.25 & 83.33 & 79.17 & 77.78 & 75.00 \\
\hline Rumiñahui & 112,603 & 83.02 & 66.67 & 87.50 & 88.89 & 87.50 \\
\hline Salinas & 92,017 & 67.92 & 83.33 & 54.17 & 77.78 & 75.00 \\
\hline Santa Elena & 184,642 & 62.26 & 41.67 & 66.67 & 66.67 & 75.00 \\
\hline Santo Domingo & 450,694 & 75.47 & 75.00 & 66.67 & 88.89 & 87.50 \\
\hline
\end{tabular}




\begin{tabular}{lrr|rrrr} 
Tulcán & 101,234 & 62.26 & 41.67 & 70.83 & 55.56 & 75.00 \\
Vinces & 81,630 & 62.26 & 58.33 & 66.67 & 44.44 & 75.00 \\
\hline
\end{tabular}

We recognize that these indicators may not offer a complete measurement of the extent to which eGov services are available and used. Nevertheless, considering the limitations of data availability at a local level in developing countries, the data may still provide a clear picture of the current digital development in the municipality context and allow us to correlate this digital development with the e-government development. Table IV shows the summary statistics of the indicators used in this study.

Table IV. Descriptive statistics of the variables

\begin{tabular}{lrrrr}
\hline Acronym & Mean & Std. Dev. & Minimum & Maximum \\
\hline Age (\% pop>60) & 10.12 & 1.55 & 5.34 & 12.70 \\
Education & 93.01 & 4.35 & 80.66 & 98.84 \\
Gender (\% Women) & 50.59 & 1.35 & 46.90 & 52.77 \\
Income & 402.79 & 591.75 & 38.59 & $2,936.91$ \\
Rurality & 441.65 & 792.11 & 12.99 & $4,641.79$ \\
ICT Use & 59.13 & 10.11 & 39.73 & 81.38 \\
eGov & 70.31 & 11.52 & 46.23 & 94.34 \\
\hline
\end{tabular}

\section{Results}

The ordinary least squares (OLS) model was estimated using the software Statistical Analysis System $\left(\mathrm{SAS}^{\circledR}\right)$. As recommended by Neter, Wasserman, and Kutner (1985), we conducted a series of tests to assess the appropriateness of the model. More specifically, we analysed the data with $\mathrm{SAS}^{\circledR}$ and then looked for normally distributed residuals by conducting a visual inspection and administering the Shapiro \& Wilk (1965) test. The correlations between the explanatory variables and values for variance inflation factors (VIF) indicate that multicollinearity is not a problem for our model. The highest value for VIF is 1.238, well below the threshold of 10 (Bollinger et al., 1981), meaning that the independent variables in the model are not highly correlated with other independent variables, and therefore the coefficients are reliable. With respect to a possible heteroscedasticity problem in the model, White's test (White, 1980) was employed, which indicated no presence of heteroscedasticity $(p>0.10)$, confirming the visual analysis of ICT usage. For a $1 \%$ significance level, the overall model is significant $(p<0.01)$.

Three of the five hypotheses were confirmed. Income $(H 2: \beta=0.563, p<0.01)$ and education (H3: $\beta=0.475, p<0.01$ ) were confirmed as drivers of ICT usage at middle-sized Ecuadorian city levels. 
On the other hand, contrary to what was hypothesised, age (H3: $\beta=0.009, p>0.10)$, and rurality ( $H 4: \beta=-0.153, p>0.10$ ) were not. Overall the model explains $58.5 \%$ of the variation (R-Square) of ICT usage. As for eGovernment availability, as expected, ICT usage seems to play an important role ( $H 5: \beta=0.519, p<0.01)$. The first is explained by $26.9 \%$ by the latter. The results are presented in Table $V$ and Figure 3.

Table V. OLS results

\begin{tabular}{llll}
\hline Variables & Parameter $(\beta)$ & p-value & VIF \\
\hline Dependent Variable: ICT Use & & & \\
Age & $0.149 \mathrm{~ns}$ & $>0.10$ & 1.124 \\
Education & $0.539 * * *$ & $<0.01$ & 1.238 \\
Income & $0.313^{* *}$ & $<0.05$ & 1.202 \\
Rurality & $0.093 \mathrm{~ns}$ & $>0.10$ & 1.109
\end{tabular}

Dependent Variable: eGov ICT Use $0.410 * * * \quad<0.001$

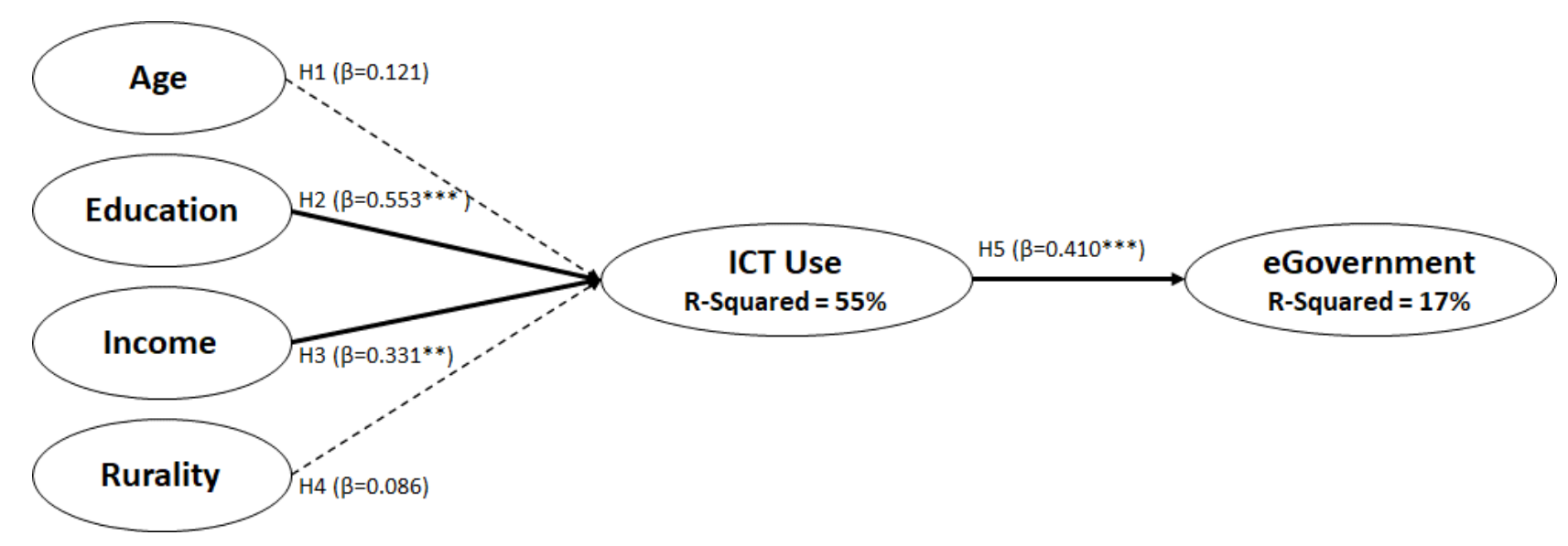

Figure 3. Results from the model assessment Note: $* p<0.10 ; * * p<0.05 ; * * *<0.01$. Non-significant relationships in dotted lines.

\section{Discussion}

The following subsections discuss the results of our empirical analysis. These are separated by implications to the digital divide and eGovernment literature.

\subsection{Implications for the digital divide}


Our substantive results have several implications for digital divide researchers and policymakers. Age, which is often pointed to as the most critical driver of digital inequalities (Elena-Bucea et al., 2020), seems to play no role in ICT usage across Ecuadorian cities. It seems that municipalities with a higher percentage of people above 60 years old do not have lower ICT usage levels. This aspect is a typical example of how context is important and that a driver of the digital divide in a specific context might play the most important role while in others is negligible. Aging is a problem (much) more noticeable in developed western countries, especially in Europe. On the other hand, in developing countries, including Ecuador, this is not the case. Hence, the percentage of the elderly in the total population is not substantial, helping to explain the fact that our hypothesis was not confirmed. The average age of Ecuadorians is 29.32 years old. In the municipality with the lowest average age, this figure is 24.72 , whereas in the one with the highest it is 32.01 . Likewise, the percentage of people who are 60 years old or older, as a percentage of the economically active population, ranges between $9.40 \%$ and $21.70 \%$, with the average figure at $16.82 \%$. Again, this finding highlights the importance of analysing the digital divide in different contexts, as results may vary substantially. This is especially crucial in the case of developing countries, especially at a regional level, as this has been largely neglected in the literature.

As expected, education and income turned out to be significant drivers of ICT usage, thus leading to high asymmetries in it, i.e., digital divides. It is interesting to note that education even surpasses income in terms of driving ICT. One might expect that in a developing country the income disparities would exert a more substantial influence in digital inequalities. Although education (see, e.g., CruzJesus, Oliveira and Bacao, 2014) and income (Beilock and Dimitrova, 2003; Cruz-Jesus, Oliveira, et al., 2016) are definitely recognized as digital divide drivers across countries, income is usually pointed out as the more important of the two, especially in developing contexts. Nevertheless, it seems reasonable to assume that some overlapping effects exist between these two factors at a municipality level. Policymakers interested in engendering ICT uptake should indeed be aware that higher income and education will yield higher ICT usage, which, in its turn, is likely to increase income, education, and welfare (Venkatesh et al., 2020; Venkatesh and Sykes, 2013), thereby creating a virtuous cycle of growth and development. Our results in this regard stress the importance of these two dimensions on digital inclusion. The good news is that they are both actionable and are perhaps the ones that policymakers at national- and local-level can influence more easily. It is demonstrated that, at least in municipalities across Ecuador, those having higher levels of education and income are less vulnerable to fall into the dark side of the digital divide. 
Finally, rurality also turned out not to be a driver of ICT usage. This outcome is not as surprising as age because usually the latter is found to have a stronger impact (Cruz-Jesus, Oliveira and Bacao, 2018). Actually, some studies do not find rurality (especially at a country level) to be a driver of the digital divide (Cruz-Jesus, Oliveira and Bacao, 2018). Perhaps the reason has to do with the fact that the geographic unit used in our study is still relatively large, comprising areas with very different degrees of urban vs. rural character. Unfortunately, there is a trade-off between data availability and depth of analysis, in this case at a geographic level.

\subsection{Implications for the e-government}

Most of the existing literature has measured e-government development from a country-level perspective (Riggins and Dewan, 2005; Cruz-Jesus, Oliveira and Bacao, 2012; Jeff Gulati, Williams and Yates, 2014; United Nations, 2018a). A country-level analysis overlooks differences that may exist at a local level. The disparities at a city or municipality level may be more challenging to understand than the disparities at a country level, as many of the indicators used in the literature are not available at a municipality level; for instance, the Income inequality index (Gini) (World Bank, 2006; Zhao, Collier and Deng, 2014), Gross Domestic Product (GDP) (United Nations, 2018c), or cultural factors (Hofstede, 1993; Zhao, Shen and Collier, 2014). This study provides several practical implications for researchers and local governments.

First, the differences in digital development and the availability of e-government services between municipalities within the same country can be surprisingly high in the context of developing countries. Researchers that study e-government development should explore new factors at the municipality level, allowing them to provide more fine-grained insights for the strategic planning of local governments. The results confirmed three hypotheses (income and education over ICT usage and ICT usage over eGov services availability). The other two hypotheses were rejected.

Second, although all of the e-government websites had some features in common (for instance, the description of budget or news about activities within the municipality), they followed a different design. This element could be a common limitation in many developing countries that may increase the costs of e-government development for local governments. This finding has implications for policymakers. We suggest that this limitation could be mitigated by adopting a common framework of standards for the development of e-government websites and the online services provided to citizens. 
Third, the access of the population to technological devices such as a computer or smartphone and connection to the Internet is fundamental for eGov services adoption. This study confirms the strong relationship between ICT use and the availability of eGov services (Zhao, Collier and Deng, 2014; Rodrigues, Sarabdeen, and Balasubramanian, 2016). Moreover, Internet access has greatly improved in recent years in developing countries (United Nations, 2018c). This finding implies that local governments in municipalities have a solid ground to invest in the provision of eGov services. These services should also be available for mobile devices in order to be adopted by a broader range of citizens (Ingrams, 2015; Jones et al., 2017). The literature shows that the evolution and availability of eGov services promote online citizen participation and therefore increase satisfaction and trust with local governments (Welch, Hinnant and Moon, 2005).

Fourth, as the levels of smartphone adoption are high in developing countries, local governments should develop mobile-oriented e-participation tools (Naranjo Zolotov, Oliveira and Casteleyn, 2018). Local governments around the world are using online social networks to provide communications and interact with their citizens (Mou et al., 2013; Tsai et al., 2012), and the municipalities analysed in this study are not the exception. Online social networks make it easier for citizens to be informed about local government plans, events, and activities; however, their function as tools for online citizen participation may still be limited. For instance, a process of online deliberation or an online decision-making process may be quite challenging to carry out using only an online social network.

Fifth, regarding the population density of the city (rurality), the results were not statistically significant on ICT usage. This finding was contrary to the originally proposed hypothesis that the effect of larger areas is negative over the ICT usage according to the rationale that larger geographical areas are more challenging to supply with IT infrastructure (Cruz-Jesus, Oliveira and Bacao, 2012), and consequently, more challenging to make eGov services available. Our finding is in line with authors such as Forman (2005), who suggested that more extensive geographical areas may take greater advantage in adopting ICT to replace other forms of communication. As in current times, access to the Internet through mobile devices is no longer an issue regarding the area size of a municipality. Therefore, local governments that invest in eGov services may achieve higher levels of adoption and citizen satisfaction even in low-density areas. 
Sixth, education is represented in this study by the literacy of citizens 15 years old and older (Lee and Kim, 2018), and income is represented by the taxes collected in each city (Dias and Costa, 2013). The United Nations report (United Nations, 2016) shows that countries with higher levels of eGov development are also the countries with higher levels of education and economic wealth. At the municipality level, this remains true. In our study, education and income were strongly associated with internet usage and, therefore, relevant for the potential adoption of eGov services. This finding suggests that local governments may envision and invest in more advanced eGov services in municipalities that have reached high levels of literacy. For instance, eGov services in the context of Smart Cities (Abu-Tayeh, Neumann and Stuermer, 2018) or electronic decision-making processes (Naranjo-Zolotov, Oliveira, Casteleyn, et al., 2019). On the other hand, for municipalities that have still not reached high levels of literacy, local governments may invest in improving and promoting existing eGov services.

Finally, by decomposing the LOSI results into its four components (Table III), it becomes clear that the major disparities between municipalities are visible in the online service component. This implies that local governments should include as a priority in their strategic planning the implementation of online services that require user authentication, and consequently, design data privacy and protection policies. Providing data accessibility and updated capabilities to the citizens may significantly alleviate the burden that local governments have when their services are not provided fully online (Veeramootoo, Nunkoo and Dwivedi, 2018).

\subsection{Limitations and future research}

The first limitation of this study is the data that are available at different levels of aggregation by the INEC (INEC, 2017). This limitation resulted in a relatively small sample size (36 municipalities), and consequently may have some impact on the accuracy of the indicators. However, the data are still appropriate to provide a picture of the differences that exist in the digital development between Ecuadorian municipalities. The second limitation is that most of the items in the LOSI scale are related to the content provision component, leaving the component of participation and engagement with the smallest weight. Moreover, smartphones are highly adopted in both developed and developing countries. Nevertheless, the LOSI scales do not consider specific items to assess mobile government (m-government). Consequently, future research may focus on the development of a new scale or an update of the existing LOSI scale to provide items to measure the development of mobile e-government and e-participation tools in greater detail. 
Besides the variables chosen for this study, many other factors may influence eGov services development in developing countries; for instance, the national culture (Zhao, 2011) or the level of human capital (United Nations, 2018a). Even though Ecuador is an interesting context in which to study e-government development amongst developing countries, caution is advised when generalizing the implications of this study to other developing countries. Future research may carry out comparative studies in other developing and developed countries at a local level to draw new insights.

\section{Conclusion}

The disparities in eGov services development exist not only at a country level. This study provides evidence that the differences in digital development and e-government development between municipalities can be surprisingly high in developing countries. We used the LOSI scale, developed by the United Nations, to assess eGov services levels in Ecuadorian municipalities. Then we explored the potential drivers that may explain the differences in the levels of eGov services. The evaluation of a research model using OLS regression provides evidence that the main driver of eGov services development is the level of internet use in the population. The levels of literacy and income were statistically significant in our model. Surprisingly, traditional drivers of ICT access and usages, such as age and rurality, were not statistically significant, implying that these two drivers may be crucial at a country level but not important enough at a municipality level when providing eGov services to the population. 


\section{References}

Abu-Tayeh, G., Neumann, O. and Stuermer, M. (2018), "Exploring the motives of citizen reporting engagement: Self-concern and other-orientation", Business \& Information Systems Engineering, Springer Fachmedien Wiesbaden, Vol. 60 No. 3, pp. 215-226.

Acedo, A., Painho, M., Casteleyn, S. and Roche, S. (2018), "Place and City : Toward Urban Intelligence”, International Journal of Geo-Information, Vol. 7 No. 9, pp. 1-21.

Adams, O. (2000), Falling through the Net: Defining the Digital Divide: A Report on the Telecommunications and Information Technology Gap in America, Journal of Government Information, Vol. 27, US Department of Commerce - Economic and Statistics Administration, Washington, D.C., available at:https://doi.org/10.1016/s1352-0237(00)00138-6.

Al-Hujran, O., Al-Debei, M. and Al-Lozi, E. (2014), "Examining eDemocracy adoption intention for digital society: An integrative model", The Eighth International Conference on Digital Society, pp. 39-47.

Almuraqab, N.A.S. (2017), "M-government adoption factors in the UAE: A partial least-squares approach", International Journal of Business and Information, Vol. 11 No. 4, pp. 404-431.

Andersen, K.N., Medaglia, R., Vatrapu, R., Henriksen, H.Z. and Gauld, R. (2011), "The forgotten promise of e-government maturity: Assessing responsiveness in the digital public sector", Government Information Quarterly, Elsevier Inc., Vol. 28 No. 4, pp. 439-445.

Asmi, F., Zhou, R. and Lu, L. (2017), "E-government Adoption in Developing Countries : Need of Customer-centric Approach : A Case of Pakistan", International Business Research, Vol. 10 No. 1, pp. 42-58.

Azam, M.S. (2015), E-Services Adoption: Processes by Firms in Developing Nations, Advances in Business Marketing and Purchasing, Vol. 23, available at:https://doi.org/10.1108/S10690964201523A.

Van Bardeleben, M. (2011), "Lessons on Information and Communication Technologies for Social Change from the Immigrant Rights Movement", European Coatings Journal, Vol. 46 No. 11, pp. 38-40.

Barnard, Y., Bradley, M.D., Hodgson, F. and Lloyd, A.D. (2013), "Learning to use new technologies by older adults: Perceived difficulties, experimentation behaviour and usability", Computers in Human Behavior, Vol. 29 No. 4, pp. 1715-1724.

Bataineh, L. and Abu-Shanab, E. (2016), "How perceptions of e-participation levels influence the intention to use e-government websites", Transforming Government: People, Process and Policy, Vol. 10 No. 2, pp. 315-334.

Beilock, R. and Dimitrova, D. V. (2003), "An exploratory model of inter-country Internet diffusion", Telecommunications Policy, Vol. 27 No. 3-4, pp. 237-252.

Bélanger, F. and Carter, L. (2009), "The impact of the digital divide on e-government use", Communications of the ACM, Vol. 52 No. 4, p. 132.

Billon, M., Marco, R. and Lera-Lopez, F. (2009), "Disparities in ICT adoption: A multidimensional approach to study the cross-country digital divide", Telecommunications Policy, Pergamon, 
Vol. 33 No. 10-11, pp. 596-610.

Blank, G. (2013), "WHO CREATES CONTENT?: Stratification and content creation on the Internet", Information Communication and Society, Routledge, Vol. 16 No. 4, pp. 590-612.

Bollinger, G., Belsley, D.A., Kuh, E. and Welsch, R.E. (1981), "Regression Diagnostics: Identifying Influential Data and Sources of Collinearity", Journal of Marketing Research, Wiley, Vol. 18 No. 3, p. 392.

Bonsón, E., Torres, L., Royo, S. and Flores, F. (2012), “Local e-government 2.0: Social media and corporate transparency in municipalities", Government Information Quarterly, Elsevier Inc., Vol. 29 No. 2, pp. 123-132.

Bowen, J.D. (2011), "Multicultural Market Democracy: Elites and Indigenous Movements in Contemporary Ecuador", Journal of Latin American Studies, Vol. 43 No. 3, pp. 451-483.

Bresnahan, T.F. and Trajtenberg, M. (1995), “General purpose technologies 'Engines of growth'?”, Journal of Econometrics, Vol. 65, pp. 83-108.

Carlsson, B. (2004), "The Digital Economy: What is new and what is not?", Structural Change and Economic Dynamics, Vol. 15 No. 3, pp. 245-264.

Castells, M. and Himanen, P. (2011), The Information Society and the Welfare State, The Information Society and the Welfare State, 1st ed., Oxford University Press, New York, available at:https://doi.org/10.1093/acprof:oso/9780199256990.001.0001.

Cegarra-Navarro, J.G., Pachón, J.R.C. and Cegarra, J.L.M. (2012), “E-government and citizen's engagement with local affairs through e-websites: The case of Spanish municipalities", International Journal of Information Management, Elsevier Ltd, Vol. 32 No. 5, pp. 469-478.

Chris Zhao, Y. and Zhu, Q. (2014), "Effects of extrinsic and intrinsic motivation on participation in crowdsourcing contest", Online Information Review, Vol. 38 No. 7, pp. 896-917.

Çilan, Ç., Bolat, B.A. and Coskun, E. (2009), "Analyzing Digital Divide Within and Between Member and Candidate Countries of European Union", Government Information Quarterly, Vol. 26, pp. 98-105.

Cruz-Jesus, F., Oliveira, T. and Bacao, F. (2012), "Digital divide across the European Union", Information \& Management, Elsevier B.V., Vol. 49 No. 6, pp. 278-291.

Cruz-Jesus, F., Oliveira, T. and Bacao, F. (2014), "Exploring the Pattern between Education Attendance and Digital Development of Countries", Procedia Technology, Vol. 16 No. 0, pp. 452-458.

Cruz-Jesus, F., Oliveira, T. and Bacao, F. (2018), "The global digital divide: Evidence and drivers", Journal of Global Information Management, Vol. 26 No. 2, pp. 1-26.

Cruz-Jesus, F., Oliveira, T., Bacao, F. and Irani, Z. (2016), "Assessing the pattern between economic and digital development of countries", Information Systems Frontiers, No. February, pp. 120.

Cruz-Jesus, F., Vicente, M.R., Bacao, F. and Oliveira, T. (2016), "The education-related digital divide: An analysis for the EU-28", Computers in Human Behavior, Elsevier Ltd, Vol. 56 No. March, pp. 72-82. 
Ćukušić, M., Alfirević, N., Granić, A. and Garača, Ž. (2010), "e-Learning process management and the e-learning performance: Results of a European empirical study", Computers and Education, Vol. 55 No. 2, pp. 554-565.

Czaja, S.J. and Lee, C.C. (2007), "The impact of aging on access to technology", Universal Access in the Information Society, Vol. 5 No. 4, pp. 341-349.

Das, A., Singh, H. and Joseph, D. (2017), "A longitudinal study of e-government maturity", Information \& Management, Elsevier B.V., Vol. 54 No. 4, pp. 415-426.

van Deursen, A. and van Dijk, J. (2015), "Toward a Multifaceted Model of Internet Access for Understanding Digital Divides: An Empirical Investigation", The Information Society, Vol. 31 No. 5, pp. 379-391.

Van Deursen, A.J.A.M., Van Dijk, J.A.G.M. and Ten Klooster, P.M. (2015), "Increasing inequalities in what we do online: A longitudinal cross sectional analysis of Internet activities among the Dutch population (2010 to 2013) over gender, age, education, and income", Telematics and Informatics, Vol. 32 No. 2, pp. 259-272.

van Deursen, A.J.A.M. and Helsper, E.J. (2015), "The Third-Level Digital Divide: Who Benefits Most from Being Online?", Communication and Information Technologies Annual, pp. 29-52.

van Deursen, A.J.A.M. and Helsper, E.J. (2018), "Collateral benefits of Internet use: Explaining the diverse outcomes of engaging with the Internet", New Media and Society, Vol. 20 No. 7, pp. 2333-2351.

Van Deursen, A.J.A.M. and Helsper, E.J. (2018), “Collateral benefits of Internet use: Explaining the diverse outcomes of engaging with the Internet", New Media and Society, Vol. 20 No. 7, pp. 2333-2351.

Dewan, S. and Riggins, F.J. (2005), The Digital Divide: Current and Future Research Directions, The Digital Divide Journal of the Association for Information Systems, Vol. 6, available at: https://pdfs.semanticscholar.org/d6c1/18d8c0461b350e9925103db435776714781d.pdf (accessed 31 July 2019).

Dias, G.P. and Costa, M. (2013), "Significant socio-economic factors for local e-government development in Portugal", Electronic Government, an International Journal, Vol. 10 No. 3, pp. 284-309.

Van Dijk, A.G.M.J. (2005), The Deepening Divide: Inequality in the Information Society, Sage Publications.

Doong, S.H. and Ho, S.-C. (2012), "The impact of ICT development on the global digital divide", Electronic Commerce Research and Applications, Elsevier B.V., Vol. 11, pp. 518-533.

Dragulanescu, N.-G. (2002), "Social Impact of the 'Digital Divide' in a Central-Eastern European Country", The International Information \& Library Review, Vol. 34 No. 2, pp. 139-151.

Eggers, W.D., Schatsky, D. and Viechnicki, P. (2017), “Al-augmented government. Using cognitive technologies to redesign public sector work", Deloitte Insights, available at: https://www2.deloitte.com/us/en/insights/focus/cognitive-technologies/artificialintelligence-government.html (accessed 5 November 2019).

Elena-Bucea, A., Cruz-Jesus, F., Oliveira, T. and Coelho, P.S. (2020), "Assessing the Role of Age, 
Education, Gender and Income on the Digital Divide: Evidence for the European Union", Information Systems Frontiers, Springer, pp. 1-15.

Epstein, D., Nisbet, E.C. and Gillespie, T. (2011), "Who's Responsible for the Digital Divide? Public Perceptions and Policy Implications", The Information Society, Routledge, Vol. 27 No. 2, pp. 92-104.

European Commission. (2010), "A Digital Agenda for Europe", Communication, Brussels, Vol. 5 No. 245 final $/ 2$, p. 42.

European Commission. (2013), Unlocking the ICT Growth Potential in Europe: Enabling People and Businesses.

Feeney, M.K. and Brown, A. (2017), "Are small cities online? Content, ranking, and variation of U.S. municipal websites", Government Information Quarterly, Elsevier Inc., Vol. 34 No. 1, pp. 6274.

Forman, C. (2005), "The corporate digital divide: Determinants of Internet adoption", Management Science, Vol. 51 No. 4, pp. 641-654.

Fozard, J.L. (1990), "Vision and Hearing in Aging", Handbook of the Psychology of Aging, Vol. 3, pp. 150-170.

Friemel, T.N. (2016), "The digital divide has grown old: Determinants of a digital divide among seniors", New Media and Society, SAGE Publications, Vol. 18 No. 2, pp. 313-331.

Gulati, G.J. "Jeff”, Williams, C.B. and Yates, D.J. (2014), "Predictors of on-line services and eparticipation: A cross-national comparison", Government Information Quarterly, Vol. 31 No. 4, pp. 526-533.

Gunkel, D.J. (2003), "Second thoughts: Toward a critique of the digital divide", New Media \& Society, Vol. 5 No. 4, pp. 499-522.

Gurstein, M. (2003), Effective Use: A Community Informatics Strategy beyond the Digital Divide.

Hassan, L. and Hamari, J. (2020), "Gameful civic engagement: A review of the literature on gamification of e-participation", Government Information Quarterly, Elsevier Ltd, Vol. 37 No. 3, p. 101461.

Heeks, R. (2018), Information And Communication Technology For Development (ICT4D), Routledge, London.

Hietala, M. (1983), The Diffusion of Innovations, Scandinavian Journal of History, Fifth Edit., Vol. 8, The Free Press, New York, available at:https://doi.org/10.1080/03468758308579015.

Hofstede, G. (1993), "Cultural constraints in management theories", The Academy of Management Executive, Vol. 7 No. 1, pp. 81-94.

Hsieh, J.J.P.A., Rai, A. and Keil, M. (2008), “Understanding digital inequality: Comparing continued use behavioral models of the socio-economically advantaged and disadvantaged", MIS Quarterly, MIS Quarterly, Vol. 32 No. 1, pp. 97-126.

Hung, S., Chang, C. and Yu, T. (2006), "Determinants of user acceptance of the e-Government services: The case of online tax filing and payment system", Government Information 


\section{Quarterly.}

Ignatow, G. (2011), "National Identity and the Informational Welfare State: Turkey and Malaysia Compared", The Information Society, Vol. 27 No. 3, pp. 158-171.

INEC. (2017), Instituto Nacional de Estadística y Censos - INEC, available at: https://www.ecuadorencifras.gob.ec (accessed 3 March 2019).

Ingrams, A. (2015), "Mobile phones, smartphones, and the transformation of civic behavior through mobile information and connectivity", Government Information Quarterly, Vol. 32 No. 4, pp. 506-515.

International Telecommunication Union (ITU). (2018a), Measuring the Information Society Report. Volume 1, Geneva, available at: https://www.itu.int/en/ITUD/Statistics/Documents/publications/misr2018/MISR-2018-Vol-1-E.pdf (accessed 10 April 2020).

International Telecommunication Union (ITU). (2018b), Measuring the Information Society Report. Volume 2. ICT Country Profiles, Geneva, available at: https://www.itu.int/en/ITUD/Statistics/Documents/publications/misr2018/MISR-2018-Vol-2-E.pdf (accessed 10 April 2020).

Jalava, J. and Pohjola, M. (2008), "The roles of electricity and ICT in economic growth: Case Finland", Explorations in Economic History, Vol. 45 No. 3, pp. 270-287.

Jones, M., Robinson, S., Pearson, J., Joshi, M., Raju, D., Charity, C.M., Wangari, S., et al. (2017), "Beyond \&quot;yesterday's tomorrow\&quot; : future-focused mobile interaction design by and for emergent users", Personal and Ubiquitous Computing, Vol. 21, pp. 157-171.

Kersting, N., Gasparikova, J. and Iglesias, A. (2016), "Local democratic renewal by deliberative participatory instruments: Participatory budgeting in comparative study", Local Public Sector Reforms in Times of Crisis, Palgrave Macmillan UK, pp. 317-331.

Khan, A. and Krishnan, S. (2021), "Citizen engagement in co-creation of e-government services: a process theory view from a meta-synthesis approach", Internet Research, available at:https://doi.org/10.1108/INTR-03-2020-0116.

Krishnan, S. and Lymm, J. (2016), "Determinants of virtual social networks diffusion: Insights from cross-country data", Computers in Human Behavior, Elsevier Ltd, Vol. 54, pp. 691-700.

Krishnan, S., Teo, T. and Lim, J. (2013), "E-Participation and e-government maturity: A global perspective", International Working Conference on Transfer and Diffusion of IT, IFIP Advances in Information and Communication Technology, vol 402. Springer, Berlin, Heidelberg, pp. 420-435.

Lee, G., Shao, B.B.M. and Vinzé, A. (2018), "The role of ICT as a double-edged sword in fostering societal transformations", Journal of the Association for Information Systems, Vol. 19 No. 3, pp. 209-246.

Lee, J. and Kim, S. (2018), “Citizens' e-participation on agenda setting in local governance: Do individual social capital and e-participation management matter?", Public Management Review, Routledge, Vol. 20 No. 6, pp. 873-895.

Lindblom, T. and Räsänen, P. (2017), "Between class and status? Examining the digital divide in 
Finland, the United Kingdom, and Greece", Information Society, Routledge, Vol. 33 No. 3, pp. 147-158.

Ma, L. and Zheng, Y. (2017), "National e-government performance and citizen satisfaction: A multilevel analysis across European countries", International Review of Administrative Sciences, pp. 1-21.

Mehr, H. (2017), "Artificial intelligence for citizen services and government", Harvard Kennedy School Ash Center for Democratic Governance and Innovation, No. August, p. 19.

Mitzner, T.L., Boron, J.B., Fausset, C.B., Adams, A.E., Charness, N., Czaja, S.J., Dijkstra, K., et al. (2010), "Older adults talk technology: Technology usage and attitudes", Computers in Human Behavior, Vol. 26 No. 6, pp. 1710-1721.

Mossberger, K., Wu, Y. and Crawford, J. (2013), "Connecting citizens and local governments? Social media and interactivity in major U.S. cities", Government Information Quarterly, Elsevier Inc., Vol. 30 No. 4, pp. 351-358.

Mou, Y., Atkin, D., Fu, H., Lin, C.A. and Lau, T.Y. (2013), "The influence of online forum and SNS use on online political discussion in China: Assessing 'spirals of trust'", Telematics and Informatics, pp. 359-369.

Naranjo-Zolotov, M., Oliveira, T. and Casteleyn, S. (2019), “Citizens' intention to use and recommend e-participation: Drawing upon UTAUT and citizen empowerment", Information Technology \& People, Vol. 32 No. 2, pp. 364-386.

Naranjo-Zolotov, M., Oliveira, T., Casteleyn, S. and Irani, Z. (2019), “Continuous usage of eparticipation: The role of the sense of virtual community", Government Information Quarterly, JAl, Vol. 36 No. 3, pp. 536-545.

Naranjo-Zolotov, M., Oliveira, T., Cruz-Jesus, F., Martins, J., Gonçalves, R., Branco, F. and Xavier, N. (2019), "Examining social capital and individual motivators to explain the adoption of online citizen participation", Future Generation Computer Systems, North-Holland, Vol. 92, pp. 302311.

Naranjo Zolotov, M., Oliveira, T. and Casteleyn, S. (2018), "E-participation adoption models research in the last 17 years: A weight and meta-analytical review", Computers in Human Behavior, Vol. 81, pp. 350-365.

Neter, J., Wasserman, W. and Kutner, M. (1985), Applied Linear Statistical Models: Regression, Analysis of Variance, and Experimental Designs, Vol. T2-A2, R. D. Irwin.

Novo, C.M. (2014), "Managing Diversity in Postneoliberal Ecuador", The Journal of Latin American and Caribbean Anthropology, Vol. 19 No. 1, pp. 103-125.

Ochara, N.M. and Mawela, T. (2015), "Enabling social sustainability of e-participation through mobile technology", Information Technology for Development, Taylor \& Francis, Vol. 21 No. 2, pp. 205-228.

OECD. (2001), "Understanding the Digital Divide".

Ojo, T. (2016), "Global agenda and ICT4D in Africa: Constraints of localizing 'universal norm'”, Telecommunications Policy, Vol. 40 No. 7, pp. 704-713. 
Ono, H. and Zavodny, M. (2007), "Digital inequality: A five country comparison using microdata", Social Science Research, Vol. 36 No. 3, pp. 1135-1155.

Park, S.R., Choi, D.Y. and Hong, P. (2015), "Club convergence and factors of digital divide across countries", Technological Forecasting and Social Change, North-Holland, Vol. 96, pp. 92-100.

Pereira, G.V., Cunha, M.A., Lampoltshammer, T.J., Parycek, P. and Testa, M.G. (2017), "Increasing collaboration and participation in smart city governance: a cross-case analysis of smart city initiatives", Information Technology for Development, available at:https://doi.org/10.1080/02681102.2017.1353946.

Radcliffe, S.A. (1999), "Reimagining the nation: community, difference, and national identities among indigenous and mestizo provincials in Ecuador", Environment and Planning A, Vol. 31, pp. 37-52.

Rodrigues, G., Sarabdeen, J. and Balasubramanian, S. (2016), "Factors that influence consumer adoption of e-government services in the UAE: A UTAUT model perspective", Journal of Internet Commerce, Vol. 15 No. 1, pp. 18-39.

Sandoval-Almazan, R. and Gil-Garcia, J.R. (2012), "Are government internet portals evolving towards more interaction, participation, and collaboration? Revisiting the rhetoric of egovernment among municipalities", Government Information Quarterly, Elsevier Inc., Vol. 29 No. SUPPL. 1, pp. S72-S81.

Sangki, J. (2018), "Vision of future e-government via new e-government maturity model: Based on Korea's e-government practices", Telecommunications Policy, Elsevier Ltd, Vol. 42 No. 10, pp. 860-871.

Scheerder, A., van Deursen, A. and van Dijk, J. (2017), "Determinants of Internet skills, uses and outcomes. A systematic review of the second- and third-level digital divide", Telematics and Informatics, Vol. 34 No. 8, pp. 1607-1624.

Shapiro, S.S. and Wilk, M.B. (1965), "An Analysis of Variance Test for Normality (Complete Samples)", Biometrika, Vol. 52 No. 3/4, p. 591.

Shirazi, F., Ngwenyama, O. and Morawczynski, O. (2010), "ICT expansion and the digital divide in democratic freedoms: An analysis of the impact of ICT expansion, education and ICT filtering on democracy", Telematics and Informatics, Pergamon, Vol. 27 No. 1, pp. 21-31.

SRI. (2018), Estadísticas Generales de Recaudación SRI - Servicio de Rentas Internas Del Ecuador, available at: https://www.sri.gob.ec/web/guest/estadisticas-generales-de-recaudacion-sri (accessed 1 June 2020).

Stratu-Strelet, D., Gil-Gómez, H., Oltra-Badenes, R. and Oltra-Gutierrez, J.V. (2021), "Critical factors in the institutionalization of e-participation in e-government in Europe: Technology or leadership?", Technological Forecasting and Social Change, Elsevier Inc., Vol. 164, p. 120489.

The World Bank. (2009), Information and Communications for Development 2009: Extending Reach and Increasing Impact, Washigton DC.

Tsai, Y.-H., Joe, S.-W., Lin, C.-P., Wang, R.-T. and Chang, Y.-H. (2012), “Modeling the relationship between IT-mediated social capital and social support: Key mediating mechanisms of sense of group", Technological Forecasting \& Social Change, Elsevier Inc., Vol. 79 No. 9, pp. 1592- 
1604.

UNESCO. (2009), "Guide to Measuring Information and Communication Technologies (ICT) in Education. UIS Technical paper; 2", Guide to Measuring Information and Communication Technologies (ICT) in Education. UIS Technical Paper; 2, p. Montreal.

United Nations. (2010), E-Government Survey 2010 Leveraging e-Government at a Time of Financial and Economic Crisis, New York, New York, USA.

United Nations. (2015a), "Transforming our world: the 2030 Agenda for Sustainable Development Transforming our world: the 2030 Agenda for Sustainable Development Preamble", United Nations General Assembly Resolution, New York.

United Nations. (2015b), Transforming Our World: The 2030 Agenda for Sustainable Development, United Nations Department of Economic and Social Affairs.

United Nations. (2016), E-Government Survey 2016 E-Government in Support of Sustainable Development, New York, New York, USA.

United Nations. (2018a), E-Government Survey 2018 Gearing e-Government to Support Transformation towards Sustainable and Resililent Societies, New York.

United Nations. (2018b), "The Sustainable Development Goals Report 2018”, edited by Affairs, D. of E. and S., New York.

United Nations. (2018c), Human Development Indices and Indicators 2018 Statistical Update, available at:

http://hdr.undp.org/sites/default/files/2018_human_development_statistical_update.pdf (accessed 4 March 2019).

United Nations Development Programme. (2016), “Human Development Report 2016: Human Development for Everyone", edited by Programme, T.U.N.D.United Nations Development Programme.

UNPAN. (2012), E-Government Survey 2012: E-Government for the People. United Nations Public Administration Network.

Valdés, G., Solar, M., Astudillo, H., Iribarren, M., Concha, G. and Visconti, M. (2011), "Conception, development and implementation of an e-Government maturity model in public agencies", Government Information Quarterly, Elsevier Inc., Vol. 28 No. 2, pp. 176-187.

Veeramootoo, N., Nunkoo, R. and Dwivedi, Y.K. (2018), "What determines success of an egovernment service? Validation of an integrative model of e-filing continuance usage", Government Information Quarterly, Elsevier, Vol. 35 No. 2, pp. 161-174.

Venkatesh, V., Rai, A., Sykes, T.A. and Aljafari, R. (2016), "Combating infant mortality in Rural India: Evidence from a field study of Ehealth Kiosk implementations", MIS Quarterly, Vol. 40 No. 2, pp. 353-380.

Venkatesh, V. and Sykes, T.A. (2013), "Digital divide initiative success in developing countries: A longitudinal field study in a village in India", Information Systems Research, INFORMS, Vol. 24 No. 2, pp. 239-260.

Venkatesh, V., Sykes, T.A., Rai, A. and Setia, P. (2019), “Governance and ICT4D initiative success: A 
longitudinal field study of ten villages in rural India", MIS Quarterly, Vol. 43 No. 4, pp. 10811104.

Venkatesh, V., Sykes, T.A. and Zhang, X. (2020), "ICT for development in rural India: A longitudinal study of women's health outcomes", MIS Quarterly, Vol. 44 No. 2, pp. 605-629.

Venkatesh, V., Thong, J. and Xu, X. (2012), "Consumer acceptance and use of information technology: Extending the unified theory of acceptance and use of technology", MIS Quarterly, Vol. 36 No. 1, pp. 157-178.

Vicente, M.R. and Gil-de-Bernabé, F. (2010), "Assessing the broadband gap: From the penetration divide to the quality divide", Technological Forecasting and Social Change, Elsevier Inc., Vol. 77, pp. 816-822.

Vicente, M.R. and López, A.J. (2010a), "What drives broadband diffusion? Evidence from Eastern Europe", Applied Economics Letters, Routledge, Vol. 17 No. 1, pp. 51-54.

Vicente, M.R. and López, A.J. (2010b), “A multidimensional analysis of the disability digital divide: Some evidence for internet use”, Information Society, Vol. 26 No. 1, pp. 48-64.

Victory, N.J. and Cooper, K.B. (2002), A Nation Online: How Americans Are Expanding Their Use of the Internet, U.S. Department of Commerce, Washington, D.C.

Weerakkody, V., Irani, Z., Kapoor, K. and Sivarajah, U. (2017), “Open data and its usability: an empirical view from the Citizen's perspective", Information Systems Frontiers, Information Systems Frontiers, Vol. 19, pp. 285-300.

Wei, K.K., Teo, H.H., Chan, H.C. and Tan, B.C.Y. (2011), "Conceptualizing and testing a social cognitive model of the digital divide", Information Systems Research, INFORMS, Vol. 22 No. 1, pp. 170-187.

Welch, E.W., Hinnant, C.C. and Moon, M.J. (2005), "Linking Citizen Satisfaction with E-Government and Trust in Government", Journal of Public Administration Research and Theory, Vol. 15 No. 3, pp. 371-391.

White, H. (1980), A Heteroskedasticity-Consistent Covariance Matrix Estimator and a Direct Test for Heteroskedasticity, Econometrica, Vol. 48, available at:https://doi.org/10.2307/1912934.

World Bank. (2006), Information and Communications for Development: Global Trends and Policies, The World Bank, Washigton DC, available at:https://doi.org/10.1596/978-0-82136346-1.

World Bank. (2016), "World Development Report, 2016: digital dividends", Choice Reviews Online, Washington, DC.

Yu, L. (2011), "The divided views of the information and digital divides: A call for integrative theories of information inequality", Article Journal of Information Science, Vol. 37 No. 6, pp. 660-679.

Zhao, F. (2011), "Impact of national culture on e-government development: a global study", Internet Research, Vol. 21 No. 3, pp. 362-380.

Zhao, F., Collier, A. and Deng, H. (2014), "A multidimensional and integrative approach to study global digital divide and e-government development", Information Technology \& People, Vol. 
27 No. 1, pp. 38-62.

Zhao, F., Scavarda, A.J. and Waxin, M.F. (2012), "Key issues and challenges in e-government development: An integrative case study of the number one eCity in the Arab world", Information Technology \& People, Vol. 25 No. 4, pp. 395-422.

Zhao, F., Shen, K.N. and Collier, A. (2014), "Effects of national culture on e-government diffusionA global study of 55 countries", Information \& Management, Vol. 51 No. 8, pp. 1005-1016.

Zolotov, M.N., Oliveira, T. and Casteleyn, S. (2018), "Continued intention to use online participatory budgeting: The effect of empowerment and habit", Proceedings of the 11th International Conference on Theory and Practice of Electronic Governance - ICEGOV '18, pp. 209-216. 